\title{
Peranan Praktek Menjahit di Lembaga Kursus dan Pelatihan (LKP) Inun: Strategi Pemberdayaan Perempuan
}

\author{
Aisyah Budi Harahap \\ FDIK IAIN Padangsidimpuan \\ (E-mail: aisyahbudiharahap@gmail.com)
}

\begin{abstract}
Abstrak: The institution aims to create skilled workers in the field of sewing clothes. The institute educates trainees totaling 20 people consisting of housewives and women dropping out of school under experienced instructors. This training runs for 3 months. It is expected that after receiving training, participants will be able to be independent and be able to open their own jobs. This study aims to determine the role of LKP Inun in empowering women through sewing skills programs, as well as the economic impact after receiving training. The research method used is in the form of a qualitative study with literature. Data obtained from interviews, non-participant observation, and documentation. The results of the study found that trainees succeeded in increasing family income. It was evident from interviews that trainees could help with their children's education costs from the results of sewing wages.
\end{abstract}

Keyword: Empowerment, Female.

Abstrak: Program keterampilan menjahit Lembaga yang bertujuan menciptakan tenaga terampil dibidang penjahitan pakaian ini memberdayakan perempuan khususnya di kota Binjai agar mampu mandiri dalam bidang perekonomian. Lembaga tersebut mendidik peserta latihan yang berjumlah 20 orang yang terdiri dari ibu rumah tangga dan wanita putus sekolah di bawah instruktur yang berpengalaman. Pelatihan ini berjalan selama 3 bulan. Diharapkan setelah mendapatkan pelatihan, peserta mampu mandiri dan bisa membuka lapangan pekerjaan sendiri. Penelitian ini bertujuan untuk mengetahui peran LKP Inun dalam memberdayakan perempuan melalui program keterampilan menjahit, serta dampak perekonomian setelah mendapatkan pelatihan. Metode penelitian yang dipakai berbentuk kualitatif dengan pendalaman pustaka. Data didapat dari wawancara, observasi non partisipan, serta dokumentasi. Hasil dari penelitian didapat bahwa peserta latihan berhasil meningkatkan pendapatan keluarga. Terbukti dari wawancara bahwa peserta latihan bisa membantu biaya pendidikan anaknya dari hasil upah menjahit.

Kata Kunci: Pemberdayaan, Perempuan 
103 Aisyah Budi Harahap, Peranan Praktek Menjahit di Lembaga Kursus dan Pelatihan (LKP) Inun: Strategi Pemberdayaan Perempuan

Jurnal At-Taghyir : Jurnal Dakwah dan Pengembangan Masyarakat Desa

Volume 1 Nomor 2 Juni 2019, h. 102-120

\section{A. Pendahuluan}

Kemiskinan pada dasarnya merupakan salah satu bentuk problema yang muncul dalam kehidupan masyarakat, khususnya masyarakat di negara-negara yang sedang berkembang. Masalah kemiskinan ini menuntut adanya suatu upaya pemecahan masalah secara berencana, terintegrasi dan menyeluruh dalam waktu yang singkat. Upaya pemecahan masalah kemiskinan tersebut sebagai upaya untuk mempercepat proses pembangunan yang selama ini sedang dilaksanakan. Istilah kemiskinan sebenarnya bukan merupakan suatu hal yang asing dalam (ekonomi). A W.Widjaya mengatakan kemiskinan ialah suatu standard tingkat hidup yang rendah, yaitu adanya suatu tingkat kekurangan materi pada sejumlah atau segolongan orang dibandingkan dengan standard kehidupan umum berlaku dalam masyarakat yang bersangkutan. Standar hidup rendah ini secara langsung kelihatan pengaruhnya terhadap kesehatan, kehidupan moral dan rasa harga diri dari mereka yang tergolong hidup miskin. ${ }^{1}$

Ketidakmajuan pembangunan sumber daya manusia dan ilmu pengetahuan teknologi merupakan permasalahan ekonomi yang ada di Indonesia. Pembangunan yang ada di Indonesia dalam jangka 25 tahun pertama hampir melupakan pentingnya pembanguan sumber daya manusia dan ilmu pengetahuan teknologi. Hal ini terbukti dari angkatan kerja di Indonesia sebanyak 140 angkatan kerja yang umurnya 10 tahun ke atas , $80 \%$ dari padanya berpendidikan setara Sekolah Dasar (SD), adapun 45 juta pekerja sudah lulus SD, sedangkan yang putus sekolah SD berjumlah 43 juta, dan jumlah pekerja pekerja yang sama sekali tidak pernah bersekolah sebanyak 20 juta. Dan selebihnya pekerja berpendidikan SLTP dan SLTA baik itu sudah lulus atau tidak lulus. Dengan pendidikan yang rendah maka produktivitas pekerja akan rendah, maka dari itu tenaga kerja yang ada di Indonesia menjadi mahal. Akibatnya produk- produk Indonesia tidak bisa bersaing dengan produk negara lain. ${ }^{2}$

Permasalahan pembangunan sumber daya manusia dan ilmu pengetahuan teknologi juga terdapat di Kelurahan Sumber Karya Kecamatan Binjai Timur. Seperti penjelasan Bapak Hotlan Panjaitan sebagai Lurah di Kelurahan Sumber Karya Kecamatan Binjai Timur penduduk di Kelurahan Sumber Karya Kecamatan Binjai

\footnotetext{
${ }^{1}$ Sahrul, Sosiologi Islam, (Medan: IAIN PRESS, 2011), h. 139

${ }^{2}$ Ikatan Alumni ITB, Pembaruan dan Pemberdayaan, (Jakarta: ITB Press, 1996), h. 47.
} 
104 Aisyah Budi Harahap, Peranan Praktek Menjahit di Lembaga Kursus dan Pelatihan (LKP) Inun: Strategi Pemberdayaan Perempuan

Jurnal At-Taghyir : Jurnal Dakwah dan Pengembangan Masyarakat Desa

Volume 1 Nomor 2 Juni 2019, h. 102-120

Timur memiliki 9.911 penduduk, adapun keluarga pra sejahtera atau keluarga yang tidak mempunyai suatu kemampuan untuk memenuhi kebutuhan dasar setiap anggotanya berjumlah 417 keluarga. Kelurahan Sumber Karya Kecamatan Binjai Timur 142 orang yang terjadi kasus pernikahan dini akibat pergaulan bebas, sehingga perempuan tidak memiliki kecakapan hidup (life skill) yang memadai untuk berperan aktif pada tataran relasi sosial. Selain pernikahan dini perempuan di Kelurahan Sumber Karya Kecamatan Binjai Timur banyak yang berpendidikan rendah, dan adapun tingkat pendidikan penduduk Kelurahan Sumber Karya Kecamatan Binjai Timur masyarakat yang tidak tamat SD 251 orang, masyarakat yang tidak tamat SLTP 327 orang, masyarat yang tidak tamat SLTA 527 orang, masyarakat yang tamat perguruan tinggi/ sarjana 173 orang, masyarakat yang tamat diploma 125 orang.

Dari jumlah tingkat pendidikan yang penulis lampirkan bahwasanya banyak masyarakat di Kelurahan Sumber Karya Kecamatan Binjai Timur yang berpendidikan yang rendah sehingga menambah problem pengangguran kerja karena potensinya tenggelam oleh keterbatasan yang memasung kreativitasnya. Demikian juga angka kemiskinan terdapat di kota Binjai. Menurut data BPS kota Binjai pada tahun 2017 terdapat jumlah penduduk miskin 18.230 jiwa penduduk. ${ }^{3}$ Data ini menunjukkan angka kemiskinan cukup tinggi di Kota Binjai dibandingkan dengan Kota Padangsidimpuan 17.760 jiwa penduduk, oleh sebab itu diperlukan sebuah lembaga yang mampu memberdayakan masyarakat miskin agar angka kemiskinan dapat ditekan.

Pemberdayaan yang dilakukan LKP yaitu dengan cara memberikan pelatihanpelatihan, mulai dari menjahit, dan membordir pakaian. Dengan adanya program LKP Inun dapat membantu ekonomi perempuan miskin di Kelurahan Sumber Karya Kecamatan Binjai Timur terutama membantu suami dalam kebutuhan rumah tangga dan menyekolahkan anak-anaknya sehingga masa depan anak-anak di Kelurahan Sumber Karya Kecamatan Binjai Timur terjamin dengan adanya bantuan dari LKP Inun. Tujuan penelitian ini adalah untuk mengetahui keadaan ekonomi masyarakat sesudah mendapat bantuan dari program keterampilan menjahit oleh Lembaga Kursus dan Pelatihan Inun

${ }^{3}$ https://binjaikota.bps.go.id/frontend/LinkTabelStatis/view/id/199, diakses tanggal 31 Maret 2019, jam 19.00 WIB. 
105 Aisyah Budi Harahap, Peranan Praktek Menjahit di Lembaga Kursus dan Pelatihan (LKP) Inun: Strategi Pemberdayaan Perempuan

Jurnal At-Taghyir : Jurnal Dakwah dan Pengembangan Masyarakat Desa

Volume 1 Nomor 2 Juni 2019, h. 102-120

di Kelurahan Sumber Karya Kecamatan Binjai Timur. Berdasarkan latar belakang di atas sejauh mana kelembagaan LKP mampu memberdayakan masyarakat miskin, meningkatkan ekonomi, dan mengurangi pengangguran di kota Binjai. Oleh sebab itu yang dibahas dalam materi ini adalah sejauh mana "peranan praktek menjahit di Lembaga Kursus dan Pelatihan (LKP) Inun: strategi pemberdayaan perempuan”.

\section{B. Tinjauan Pustaka}

1. Pemberdayaan Masyarakat

Pemberdayaan barasal dari bahasa Inggris empowerment dari kata "power" (kekuasaan atau keberdayaan), yang secara harfiah bisa diartikan sebagai "pemberkuasaan" dalam arti pemberian atau peningkatan kekuasaan kepada masyarakat yang lemah atau tidak beruntung. ${ }^{4}$ Karena itu ide utama dari pemberdayaan ini bersentuhan dengan konsep kekuasaan. Konsep kekuasaan juga sering dikaitkan dengan kemampuan individu untuk membuat orang lain melakukan apa yang diinginkannya, terlepas dari minat dan keinginan mereka. Secara konseptual pemberdayaan masyarakat adalah upaya untuk meningkatkan harkat dan martabat lapisan masyarakat yang dalam kondisi sekarang tidak mampu melepaskan diri dari perangkap kemiskinan dan keterbelakangan, dengan kata lain memberdayakan adalah kemampuan dan memandirikan masyarakat. ${ }^{5}$ Pemberdayaan pada intinya membahas bagaimana individu, kelompok ataupun komunitas berusaha mengontrol kehidupan mereka sendiri dan mengusahakan untuk membentuk masa depan sesuai dengan keinginan mereka. ${ }^{6}$

Pemberdayaan dapat dibedakan pada dua hal. Pertama, pemberdayaan sebagai upaya dalam memberikan kekuatan dan kemampuan pada individu atau kelompok agar lebih berdaya dengan adanya unsur luar, sehingga mempunyai kekuatan untuk dapat mengambil peran di lingkungannya. Kedua, memunculkan kemampuan individu atau kelompok yang selama ini masih terpendam dalam dirinya. ${ }^{7}$ Menyebut hal yang pertama sebagai kecendrungan primer dan yang keduanya sebagai kecendrungan sekunder.

\footnotetext{
${ }^{4}$ Alfitri, Community Development, (Yogyakarta: Pustaka Pelajar, 2011), h. 22.

${ }^{5}$ Aprillia, et al Pembangunan Berbasis Masyarakat, (Bandung: Cv. Alfabeta, 2014), h. 93.

${ }^{6}$ Isbandi Rukminto Adi, Intervensi Komunitas Pengembangan Masyarakat Sebagai Upaya Pemberdayaan masyarakat, (Jakarta: PT. Raja Grapindo Persada, 2008), h. 54.

${ }^{7}$ A.M.W Pranaka, Gelobalisasi Pemberdayaan dan Demokratisasi, (Jakarta : CIDES, 1997), h.
} 57. 
106 Aisyah Budi Harahap, Peranan Praktek Menjahit di Lembaga Kursus dan Pelatihan (LKP) Inun: Strategi Pemberdayaan Perempuan

Jurnal At-Taghyir : Jurnal Dakwah dan Pengembangan Masyarakat Desa

Volume 1 Nomor 2 Juni 2019, h. 102-120

Dengan kedua kecendrungan ini akan merubah individu atau kelompok dalam situasi yang serba keterbatasan dan ketidak berdayaan menjadi mempu dan mandiri dalam mendobrak segala keterbatasannya.

Maksud dari pengembangan masyarakat adalah suatu usaha dalam mentransformasikan daya kepada masyarakat dengan bermacam- macam kegiatan, agar masyarakat sadar untuk lebih menggali potensi yang ada dalam dirinya. Mampu menggunakan potensi yang ada pada alam serta tenaga, agar masyarakat mampu menggali potensi dengan melakukan kegiatan dan investasi untuk mencapai hidup kearah yang lebih baik. ${ }^{8}$ Jadi dapat dipahami bahwa pemberdayaan adalah sebuah proses yang sengaja dilakukan untuk memberikan daya dari satu kelompok masyarakat kepada kelompok masyarakat lain yang membutuhkan daya. Dengan daya tersebut mereka memiliki energi untuk melakukan sesuatu dalam kehidupannya dan untuk penghidupannya agar mereka menjadi lebih mandiri. Berkenaan dengan konsep pemberdayaan masyarakat, Winarni mengatakan bahwa inti dari pemberdayaan adalah meliputi tiga hal yaitu pengembangan (enabling), memperkuat potensi atau daya (empowerment), dan terciptanya kemandirian. ${ }^{9}$ Berdasarkan pengertian ini berarti pemberdayaan tidak saja terjadi pada masyarakat yang tidak memiliki kemampuan, akan tetapi pada masyarakat yang memiliki daya yang masih terbatas, dapat dikembangkan hingga mencapai kemandirian. Pada hakikatnya pemberdayaan merupakan penciptaan suasana atau iklim yang memungkinkan potensi masyarakat berkembang. Hal ini berdasarkan asumsi bahwa tidak ada masyarakat yang sama sekali tidak memiliki daya. Setiap masyarakat pasti memiliki daya, akantetapi mereka kurang menyadari, atau daya tersebut belum diketahui secara ekplisit. Oleh karena itu daya perlu digali, kemudian dikembangkan.

Dalam peroses pemberdayaan pemerintah memiliki peranan dalam memberikan kuasa, kebebasan dan pengakuan sehingga masyarakat dapat berkesempatan untuk menentukan masa depan dan peningkatan kualitas hidupnya dengan memakai

\footnotetext{
${ }^{8}$ Sutrisno Kh dan Mary Johnston, Membina Masyarakat Pembangunan Kasus-Kasus Pengembangan Masyarakat, (Surakarta : Yayasan Indonesia Sejahtera, 1992), h. 12.

${ }^{9}$ Winarni, Memahami Pemberdayaan Masyarakat Desa Primitif dalam Orientasi Pembangunan Masyarakat Desa Menyongsong Abad 21: Maju Pemberdayaan Pelayanan Masyarakat, (Yogyakarta: Aditya Media, 1998), h. 75.
} 
107 Aisyah Budi Harahap, Peranan Praktek Menjahit di Lembaga Kursus dan Pelatihan (LKP) Inun: Strategi Pemberdayaan Perempuan

Jurnal At-Taghyir : Jurnal Dakwah dan Pengembangan Masyarakat Desa

Volume 1 Nomor 2 Juni 2019, h. 102-120

semberdaya yang merupakan manifestasi negara. Pemerintah yang melakukan pembangunan secara merata akan dapat mengefektifkan dalam memajukan perkembangan daerahnya secara merata dengan memperhatikan tiga hal pokok: ${ }^{10}$

a. Upaya itu harus terarah ditujukan kepada yang memerlukan dan sesuai dengan kebutuhannya.

b. Program itu harus mengikut sertakan atau dilaksanakan oleh masyarakat yang menjadi sasarannya. Hal ini dimaksud agar lebih efektif, sesuai dengan kehendak dan kebutuhan mereka sekaligus meningkatkan keberdayaannya dalam merancang, mengelolah dan melaksanakan serta mempertanggung jawabkannya.

c. Mengadakan pendekatan secara kelompok agar penggunaan sumber daya lebih efisien. Kalau dengan cara sendiri-sendiri masyarakat miskin sulit dalam mangatasi masalah yang dihadapinya, ruang lingkup masalah itu juga terasa luas kalau dihadapi dengan cara inividu.

Pemberdayaan masyarakat merupakan upaya membangun kemampuan masyarakat dan memperdayakan sumber daya manusia (SDM) yang ada melalui pengembangan kelembagaan, sarana dan prasarana serta pengembangan tiga-p (pendamping, penyuluhan, dan pelayanan). Pendamping yang dapat menggerakkan partisipasi total masyarakat, penyuluhan dapat merespons dan memantau ubahanubahan yang terjadi di masyarakat, dan pelayanan yang berfungsi sebagai unsur pengendali ketepatan distribusi aset sumber daya fisik dan nonfisik yang diperlukan masyarakat.

Pemberdayaan masyarakat dapat terbukti ketika masyarakat mampu memperbaiki kehidupannya menjadi lebih baik, yang artinya tidak lagi bergantung kepada orang lain, sampai masyarakat mampu mengeluarkan ide- ide agar mampu mencapai kehidupan yang lebih baik dari kondisi sebelumnya. ${ }^{11}$ Meskipun pemberdayaan masyarakat bukan semata-mata sebuah konsep ekonomi, pemberdayaan masyarakat mengandung arti menegakkan demokrasi ekonomi. Demokrasi ekonomi

\footnotetext{
${ }^{10}$ Charles Pernama Siregar, Jalan Terjang Menuju Masyarakat Indonesia Sejahtera, (Padang: BBPPKS, 2009), h. 27.

${ }^{11}$ Randhy R. Wrihatnolo, Manajemen Pemberdayaan, (Jakarta: PT Elex Media Komputindo, 2007), h. 29.
} 
108 Aisyah Budi Harahap, Peranan Praktek Menjahit di Lembaga Kursus dan Pelatihan (LKP) Inun: Strategi Pemberdayaan Perempuan

Jurnal At-Taghyir : Jurnal Dakwah dan Pengembangan Masyarakat Desa

Volume 1 Nomor 2 Juni 2019, h. 102-120

secara harfiah berarti kedaulatan rakyat di bidang ekonomi, dimana kegiatan ekonomi yang berlangsung adalah dari rakyat, oleh rakyat dan untuk rakyat.

Pemberdayaan adalah proses, untuk itu ia mempunyai tiga tahapan, yaitu: penyadaran, pengkapasitasan, dan pendayaan. ${ }^{12}$ Lembaga yang mampu memberdayakan masyarakat miskin salah satunya adalah LKP Inun, pemberdayaan ekonomi masyarakat yang dilakukan merupakan upaya untuk mempersiapkan masyarakat yang seiring dengan upaya memperkuat kelembagaan ekonomi mikro dan kecil lokal yang ada dalam masyarakat agar komunitas ekonomi mikro tersebut mampu mewujudkan kemajuan, kemandirian dan kesejahteraan dalam suasana keadilan sosial yang berkelanjutan. Untuk itu upaya pengembangan ekonomi masyarakat adalah upaya meningkatkan harkat dan martabat lapisan masyarakat yang dalam kondisi sekarang tidak mampu (dhu'afa) untuk melepaskan diri dari perangkap- perangkap kemiskinan dan keterbelakangan yang menghinggapinya.

Pemberdayaan yang dilakukan LKP yaitu dengan cara memberikan pelatihanpelatihan, mulai dari menjahit, dan membordir pakaian. Dengan adanya program LKP Inun dapat membantu ekonomi perempuan miskin di Kelurahan Sumber Karya Kecamatan Binjai Timur terutama membantu suami dalam kebutuhan rumah tangga dan menyekolahkan anak-anaknya sehingga masa depan anak-anak di Kelurahan Sumber Karya Kecamatan Binjai Timur terjamin dengan adanya bantuan dari LKP Inun. Tujuan penelitian ini adalah untuk mengetahui keadaan ekonomi masyarakat sesudah mendapat bantuan dari program keterampilan menjahit oleh Lembaga Kursus dan Pelatihan Inun di Kelurahan Sumber Karya Kecamatan Binjai Timur.

\section{Pemberdayaan Perempuan dalam Persfektif Islam}

Pemberdayaan perempuan antara lain memberikan pelatihan, konsultasi usaha, peningkatan keteramilan secara baik, meningkatkan produk- produk yang berkualitas, dengan adanya pemberdayaan perempuan membuat perempuan menjadi lebih produktif, menyadarkan perempuan bahwasanya mereka berhak dalam dunia kerja, sosial, hukum, maupun politik. Setiap orang secara naluri berusaha untuk memenuhi kebutuhannya, bentuk usaha tersebut adalah dengan bekerja di suatu tepat baik sektor-sektor swasta

\footnotetext{
${ }^{12}$ Totok Mardikanto, poerwoko Soebiato, Perberdayaan Masyarakat Dalam Perspektif Kebijakan Publik, (Bandung: ALFABETA, 2015), h. 10.
} 
109 Aisyah Budi Harahap, Peranan Praktek Menjahit di Lembaga Kursus dan Pelatihan (LKP) Inun: Strategi Pemberdayaan Perempuan

Jurnal At-Taghyir : Jurnal Dakwah dan Pengembangan Masyarakat Desa

Volume 1 Nomor 2 Juni 2019, h. 102-120

maupun sector negri. Jerih payah itu dihargai dengan uang yang sering kali disebut dengan pendapatan, pendapatan pribadi (Personil Income) menunjukkan semua jenis pendapatan, baik diperoleh karena fungsi produksi maupun tanpa memberikan suatu kegiatan apapun, yang diterima oleh penduduk maupun suatu Negara.

Perempuan perlu diberikan pelatihan, pendidikan, bahkan suatu pemberdayaan, agar mereka memiliki kemampuan untuk hidup layak dan bisa membantu suaminya untuk memenuhi kebutuhan sehari-hari. Tujuannya agar perempuan memiliki suatu kemampuan / keahlian.Dalam konteks pekerja perempuan, ia dipersilahkan memilih bidang atau sektor yang ia sukai yang tentunya sesuai dengan kemampuan dan profesionalitas yang dimiliki. Adapun garis yang dibikin Islam sangat jelas, Allah berfirman:

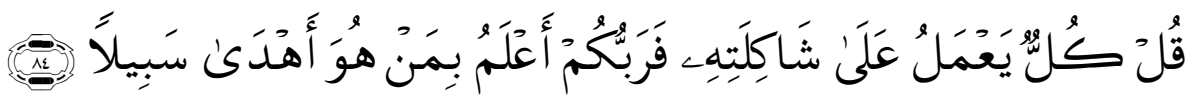

"Katakanlah setiap orang berbuat (bekerja) menurut keadaannya (skill) masingmasing, maka Tuhanmu lebih mengetahui siapa yang lebih benar jalanNya. ${ }^{13}$ (QS. Al Isra': 84).

Dari ayat tersebut dapat kita pahami perempuan juga boleh bekerja sesuai dengan keadaannya (skill) masing-masing agar dapat membantu ekonomi dalam keluarganya, "maju terus pantang mundur" slogan manusia sukses. Allah akan bersama mukmin yang berada dalam kebenaran. ${ }^{14}$ Jika memang ada sesuatu yang sangat mendesak untuk berkarirnya perempuan diluar rumah maka hal ini diperbolehkan. Namun harus dipahami bahwa kebutuhan yang mendesak ini harus ditentukan dengan kadarnya yang sesuai sebagaimana sebuah kaidah giqhiyah yang masyhur. Dan kebutuhan yang mendesak itu misalnya: ${ }^{15}$

a. Rumah tangga memerlukan kebutuhan pokok yang mengharuskan perempuan bekerja.

Misalnya karena suaminya atau orang tuanya meninggal dunia atau keluarganya

\footnotetext{
13 Al-Quran in Word

${ }^{14}$ Zainal Arifin Zakaria, Tafsir Inspirasi, (Medan: Duta Azahar, 2012), h. 322.

${ }^{15}$ M. Hasan Ali, Masail Fiqhiyah Al- Haditsah pada Masalah-Masalah Kontemporer Hukum Islam, (Jakarta: PT RajaGrafindo Persada, 1998), h. 193.
} 
110 Aisyah Budi Harahap, Peranan Praktek Menjahit di Lembaga Kursus dan Pelatihan (LKP) Inun: Strategi Pemberdayaan Perempuan

Jurnal At-Taghyir : Jurnal Dakwah dan Pengembangan Masyarakat Desa

Volume 1 Nomor 2 Juni 2019, h. 102-120

sudah tidak bisa memberikan nafkah karena sakit atau yang lainnya. Sedangkan negara tidak memberikan jaminan pada keluarga semacam mereka. Lihatlah kisah yang difirmankan Allah dalam surat Al- Qoshosh 23- 25:

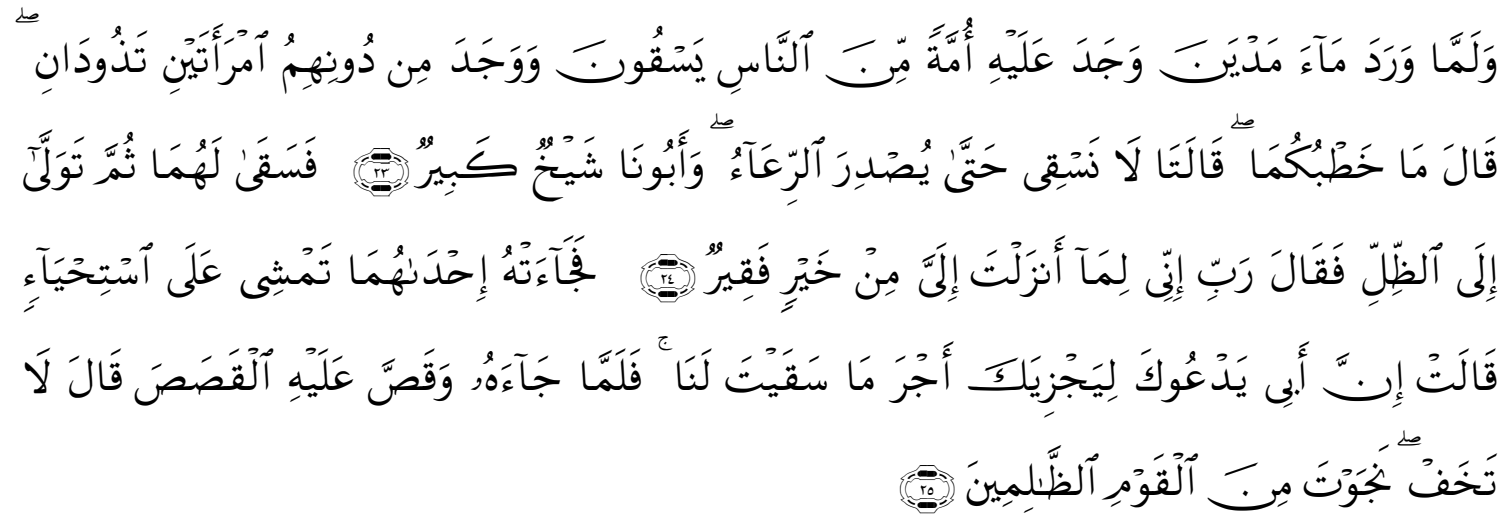

"23. Ketika dia sampai di sumber air negeri Madyan, dia menjumpai di sana sekumpulan orang yang sedang memberi minum ternaknya, dan dia menjumpai di belakang orang banyak itu, dua orang perempuan sedang menghambat ternaknya. Musa berkata, "Apakah maksudmu dengan berbuat begitu?" kedua perempuan itu menjawab, "Kami tidak dapat memberi minum ternak kami, sebelum pengembalapengembala itu memulangkan ternaknya, sedang ayah kami adalah orang tua yang telah lanjut usianya. 24. Maka Musa memberi minum ternak kedua perempuan itu, kemudian dia kembali ke tempat yang teduh lalu berdoa, "ya Tuhanku, sesungguhnya aku sangat memerlukan sesuatu kebaikan makanan yang Engkau turunkan kepadaku." 25. Kemudian datanglah kepada Musa salah seorang dari kedua perempuan itu berjalan dengan malu- malu, dia berkata, "Sesungguhnya ayahku mengundangmu untuk memberi balasan sebagai imbalan atas kebaikanmu memberi minum ternak kami." Ketika Musa mendatangi ayahnya (Syuaib) dan dia menceritakan kepadanya kisah mengenai dirinya. Syuaib berkata, "Janganlah engkau takut! Engkau telah selamat dari orang- orang zalim itu."

Perhatikan percakapan kedua perempuan pada ayat di atas "sedang ayah kami adalah orang tua yang telah lanjut usianya". Hal ini menjelaskan bahwa kedua perempuan tersebut terpaksa melakukan pekerjaan itu, dikarenakan ayah kedua perempuan tersebut sudah tua, dan sudah tidak mampu lagi melakukan pekerjaan tersebut.

b. Pekerja perempuan dibutuhkan masyarakat

Perempuan pada zaman Rasulullah saw sudah ada yang bekerja. Seperti membantu kelahiran masyarakat dan mengkhitan anak- anak perempuan. Pekerjaan perempuan pada zaman Rasulullah saw itu dikerjakan di luar rumah. Pada zaman 
111 Aisyah Budi Harahap, Peranan Praktek Menjahit di Lembaga Kursus dan Pelatihan (LKP) Inun: Strategi Pemberdayaan Perempuan

Jurnal At-Taghyir : Jurnal Dakwah dan Pengembangan Masyarakat Desa

Volume 1 Nomor 2 Juni 2019, h. 102-120

sekarang dapat dikatakan sebagai dokter perempuan spesialis kandungan dan bidan desa yang membantu persalinan masyarakat.

Pekerjaan perempuan pada zaman Rasulullah saw yang diriwayatkan oleh Anas bin Malik Radiyallahu 'Anhu berkata: "Rasulullah shallallahu 'alaihi wa sallam berperang bersama Ummu Sulaim dan beberapa perempuan anshor, maka mereka memberi minum dan mengobati orang yang terluka." Sejarah juga mencatat bahwa Siti Khadijah istri pertama Rasulullah saw juga menjadi perempuan karir, yaitu dalam bidang sektor perniagaan. Sayyidina Khadijah perempuan karir pertama kali dalam sejarah Islam, Rasulullah saw telah melakukan akad mudharabah (akad bagi keuntungan) bersamanya. Sayyidah Khadijah juga melakukan ekspor impor komoditi secara internasional. Kafilah niaganya membentang dari negeri yaman ke negeri syiria, dan terus bekerja di musim panas dan dingin beliau termasuk orang pertama yang menghilangkan sekat-sekat dan membuka pintu selebar- lebarnya bagi perempuan untuk terjun di dunia bisnis.

Islam memberikan semangat bagi laki- laki dan perempuan untuk selalu aktif dalam bekerja. Allah berfirman dalam surah An- Nahl ayat 97:

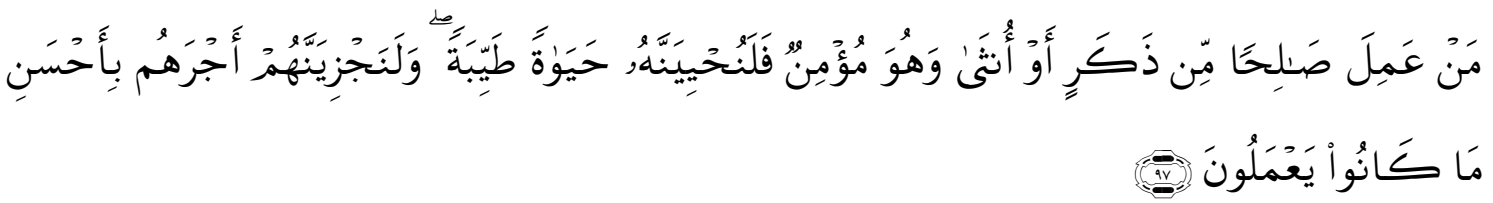

"Barangsiapa mengerjakan kebaikan, baik laki- laki maupun perempuan dalam keadaan beriman, maka pasti akan Kami berikan kepadanya kehidupan yang baik dan akan Kami beri balasan dengan pahala yang lebih baik dari apa yang telah mereka kerjakan. "16

Sudah jelas ayat di atas menyatakan bahwa laki- laki dan perempuan dalam Islam mendapat pahala yang sama dan bahwa amal kebaikan harus disertai iman. Keimanan yang sungguh- sungguh berarti sikap dan tingkah laku yang baik. laki- laki dan perempuan juga sama- sama berhak untuk aktif di dunia kerja. Laki- laki dan perempuan tidak ada perbedaan dalam berkarir, akan tetapi laki- laki dan perempuan harus bisa memilih pekerjaan sesuai dengan kodrat masing- masing.

${ }^{16}$ Al-Quran in Word 
112 Aisyah Budi Harahap, Peranan Praktek Menjahit di Lembaga Kursus dan Pelatihan (LKP) Inun: Strategi Pemberdayaan Perempuan

Jurnal At-Taghyir : Jurnal Dakwah dan Pengembangan Masyarakat Desa

Volume 1 Nomor 2 Juni 2019, h. 102-120

Ajaran Islam menjelaskan bahwa apapun jabatan yang dipegang perempuan dalam dunia kerja, tugas utama perempuan adalah sebagai ibu rumah tangga. Karena ibu itu sebagai pendidik pertama bagi anak- anaknya di rumah yang harus mengajarkan anak- anaknya dengan baik. Hancurnya suatu negara sangat berkaitan dengan pendidikan yang diajarkan di rumah, jika pendidikan yang diajarkan ibu baik kepada anak- anaknya maka akan membentuk suatu negara yang baik pula. Ajaran Islam juga memperbolehkan perempuan bekerja, akan tetapi perempuan juga harus bisa seimbang mengurus antara rumah tangga dan dunia kerja.

\section{Peran LKP Inun dalam Memberdayakan Perempuan Muslimah}

1. Pemberian Dana Dari Pemerintah Kepada Perempuan Muslimah

Bantuan langsung ekonomi merupakan kegiatan pemberian uang secara langsung kepada masyarakat untuk memenuhi kehidupannya sehari-hari. Bantuan langsung ekonomi bersifat konsumtif yang diperuntukkan bagi perempuan yang membutuhkannya, meskipun merupakan bantuan langsung merupakan pemberian secara cuma-cuma, namun tetap diperlukan kegiatan yang harus dipahami oleh SDM pelaksana sehingga diperoleh kesamaan pandangan dan mekanisme penyalurannya, oleh karena itu intruksi kerja ini dibuat untuk memaparkan ketentuan dan standar dalam kegiatan bantuan langsung ekonomi.

Calon penerima manfaat mempunyai syarat agar bisa mengikuti pelatihan menjahit dari LKP Inun yaitu individu atau kelompok masyarakat yang ekonominya menengah ke bawah, harus beragama Islam, mengisi formulir pendaftaran penerima manfaat penyertaan kelengkapan administrasi sebagai berikut: fotocopy KTP, surat dari aparat setempat yakni surat keterangan tidak mampu. Bantuan langsung ekonomi dari Pemerintah langsung disalurkan dalam bentuk:

a. Dana

Dana yang diberikan pemeritah kepada perempuan muslimah di Kelurahan Sumber Karya Kecamatan Binjai Timur sebanyak Rp 1.700.000 per orang, yang mana dana ini dikeluarkan pemerintah selama tiga bulan sekali. Dana tersebut diberikan pemerintah kepada LKP Inun agar dapat memberikan pelatihan menjahit kepada perempuan muslimah di Kelurahan Sumber Karya Kecamatan Binjai Timur. Dan adapun murid yang diberikan pelatihan oleh LKP Inun berjumlah 20 orang. 
113 Aisyah Budi Harahap, Peranan Praktek Menjahit di Lembaga Kursus dan Pelatihan (LKP) Inun: Strategi Pemberdayaan Perempuan

Jurnal At-Taghyir : Jurnal Dakwah dan Pengembangan Masyarakat Desa

Volume 1 Nomor 2 Juni 2019, h. 102-120

Selain dana belajar yang diberikan pemerintah kepada perempuan muslimah, pemerintah juga memberi dana transportasi kepada perempuan muslimah di Kelurahan Sumber Karya Kecamatan Binjai Timur sebesar Rp. 50.000 setiap bulannya. Dana tranportasi yang diberikan pemerintah tersebut agar dapat mempermudah perempuan muslimah di Kelurahan Sumber Karya Kecamatan Binjai Timur dalam mengikuti pelatihan menjahit yang diberikan oleh LKP Inun.

b. Peralatan menjahit

Peralatan menjahit yang diberikan seperti mesin jahit, benang, jarum dll. Bantuan pemerintah tersebut diamanahkan kepada LKP Inun, agar dapat melatih menjahit kepada perempuan muslimah, yang dimana pelatihan menjahit ini dapat menjadi modal utama bagi perempuan di Kelurahan Sumber Karya Kecamatan Binjai Timur untuk dapat memperbaiki ekonomi dalam keluarga.

2. Pelatihan Yang Diberikan LKP Inun Kepada Perempuan Muslimah

Menurut Ibu Nurainun (ketua LKP Inun), pelatihan praktek menjahit bertujuan agar dapat meningkatkan ekonomi perempuan di Kelurahan Sumber Karya Kecamatan Binjai Timur dan perempuan yang sudah diajarkan menjahit dapat membuka usaha menjahit. Adapun profile terbentuknya pelatihan menjahit di LKP Inun adalah sebagai berikut:

a. Pelatih

Peran pelatih dalam praktek menjahit sangat penting. Tugas pelatih untuk mengajarkan para peserta pelatihan menjahit dengan benar dan pelatih juga memberi motivasi kepada peserta untuk selalu semangat menjahit. Agar perekonomian perempuan membaik. Adapun yang menjadi pelatihan menjahit di Kelurahan Sumber Karya Kecamatan Binjai Timur adalah Ibu Nurainun. Ibu Nurainun adalah seorang yang sudah berpengalaman dalam dunia menjahit.

b. Peserta

Peserta yang ikut praktek menjahit memang belum banyak, adapun jumlah peserta dalam prakter menjahit di Kelurahan Sumber Karya Kecamatan Binjai Timur berjumlah 20 orang. Jumlah peserta praktek menjahit sedikit, karena memang hanya perempuan yang tinggal di Kelurahan Sumber Karya Kecamatan Binjai Timur saja yang boleh mengikuti pelatihan keterampilan menjahit dan bantuan dana dari pemerintah juga 
114 Aisyah Budi Harahap, Peranan Praktek Menjahit di Lembaga Kursus dan Pelatihan (LKP) Inun: Strategi Pemberdayaan Perempuan

Jurnal At-Taghyir : Jurnal Dakwah dan Pengembangan Masyarakat Desa

Volume 1 Nomor 2 Juni 2019, h. 102-120

terbatas. Perempuan yang akan diberikan pelatihan keterampilan menjahit sangat bersemangat dalam pelatihan karena menurut Ibu Nurainun "praktek menjahit dapat meningkatkan perekonomian perempuan". Menurut hasil wawancara, para peserta pelatihan menjahit di LKP Inun sudah banyak yang berhasil. Para peserta sesudah mengikuti pelatihan menjahit di LKP Inun mereka membuka toko pakaian dari hasil jahitan tersebut dan menerima pesanan jahitan.

c. Waktu dan Lokasi Prakter Keterampilan Menjahit

Praktek keterampilan menjahit berlangsung dalam waktu 3 bulan. Pertemuan praktek menjahit diadakan seminggu tiga kali yaitu hari selala, kamis, dan sabtu. Pelatihan ini dilaksanakan hanya 2 jam mulai dari jam 16.00- 18.00 WIB. Pelatihan keterampilan menjahit diadakan di rumah Ibu Nurainun ketua LKP Inun.

d. Kurikulum Pelatihan Keterampilan Menjahit

1) Pengetahuan dasar mengenai mesin

Tahap pertama pelatih akan memperkenalkan kepada peserta pelatihan pengetahuan dasar mengenai mesin, mereka akan diajarkan bagaimana menjaga mesin jahit dengan baik karena mesin jahit sangat cepat rusak jika tidak digunakan dengan hati- hati. Pengetahuan dasar mengenai mesin akan dipelajari selama seminggu. Hasil wawancara peneliti dengan Ibu Ermaini “dalam tahap pertama praktek menjahit peserta harus betul- betul mengetahui berbagai mesin jahit, diantaranya yaitu: mesin satu, mesin obras, mesin utama dan mesin lainnya.

2) Pelajaran memasang jarum dengan tidak memakai benang di atas kertas

Peserta belajar memasang jarum dengan tidak menggunakan benang di atas kertas, dan peserta mulai menjahit lurus, belok, serta menyudut. Hal ini dipelajari agar peserta tidak kaku dan mulai terbiasa menggunakan jarum.

3) Pelajaran memakai jarum dengan menggunakan benang di atas kertas

Setelah peserta sudah terlatih menjahit menggunakan jarum dengan tidak menggunakan benang di atas kertas, selanjutnya peserta akan belajar menjahit dengan menggunakan benang di atas kertas. Perbedaan materi ini dengan materi sebelumnya yaitu pemakaian benang. Pada tahap ini pelatih akan melihat peserta sudah lancar atau tidak menjahit dengan menggunakan benang di atas kertas. Jika peserta sudah lancar mereka dapat menjahit dengan menggunakan kain, akan tetapi jika peserta belum lancar 
115 Aisyah Budi Harahap, Peranan Praktek Menjahit di Lembaga Kursus dan Pelatihan (LKP) Inun: Strategi Pemberdayaan Perempuan

Jurnal At-Taghyir : Jurnal Dakwah dan Pengembangan Masyarakat Desa

Volume 1 Nomor 2 Juni 2019, h. 102-120

mereka akan terus belajar menjahit di atas kertas sampai peserta lancar dan terbiasa. Materi ini biasanya pada pertemuan minggu ke III.

4) Pelajaran menjahit menggunakan kain

Sesudah lancar memakai jarum dengan menggunakan benang di atas kertas, peserta sudah dapat menjahit dengan menggunakan kain. Pada tahap ini pelatih akan memberikan peserta pelatihan bahan, kemudian pelatih memerintah peserta pelatihan untuk menyatukan bahan tersebut untuk menjadi suatu jahitan. Para peserta pelatihan bebas ingin menjahit apa saja. Pada tahapan ini pelatih mengharapkan peserta dapat menjahit menggunakan kain.

5) Pelajaran membuat pola

Pelajaran membuat pola merupakan dasar menjahit yang akan dibuat para peserta pelatihan sebelum membuat suatu kerajinan. Tahap belajar membuat pola ini pelatih akan mengajarkan berbagai macam bentuk pola, pelatih akan mengajarkan menjahit yang sederhana terlebih dahulu seperti: sapu tangan, bantalan jarum pentul, penutup kulkas dan lain sebagainya. Dan jika pembuatan pola ini jahitannya rapi maka hasil jahitan ini akan dipasarkan. Dan hasil penjualan tersebut akan diberikan kepada peserta pelatihan.

6) Pelajaran prakter membuat kerajinan

Pelajaran praktek membuat kerajinan merupakan inti dari praktek menjahit. Pelatih akan memperhatikan para peserta sejauh mana mereka mampu menjahit. Kemudian pelatih memerintah para peserta untuk membuat perlak memasak, ini adalah kerajinan yang mudah agar peserta terbaiasa menjahit. Jika sudah mampu menjahit parlak memasak pelatih akan mengajarkan model- model jahitan yang lain. Prakter membuat kerajinan memakan waktu yang cukup lama, karena praktek membuat kerajinan merupakan inti dari praktek menjahit. Pada tahapan ini peserta harus mampu membuat suatu kerajinan. Dari hasil kerajinan para peserta dapat membuka usaha kecil di rumah para peserta. Dengan usaha ini dapat meningkatkan ekonomi perempuan di Kelurahan Sumber Karya Kecamatan Binjai Timur.

7) Ujian menjahit

Sesudah mempelajari semua hal tentang materi menjahit. Jahitan yang akan diuji yaitu membuat suatu kerajinan yang telah dipelajari. Ujian menjahit ini akan diberikan 
116 Aisyah Budi Harahap, Peranan Praktek Menjahit di Lembaga Kursus dan Pelatihan (LKP) Inun: Strategi Pemberdayaan Perempuan

Jurnal At-Taghyir : Jurnal Dakwah dan Pengembangan Masyarakat Desa

Volume 1 Nomor 2 Juni 2019, h. 102-120

waktu dari jam 07.00 WIB - 16.00 WIB. Dalam waktu yang ditentukan peserta harus mampu menyelesaikan kerajinan menjahit. Karena pada akhir pertemuan peserta akan diberikan sertifikat bagi yang lulus ujian, namun jika peserta tidak lulus ujian maka tidak akan mendapatkan sertifikat. Sertifikat sangat berguna untuk melamar pekerjaan di perusahaan garmen.

\section{Pemasaran Produk Yang Dilakukan LKP Inun}

LKP Inun memberi bantuan kepada perempuan muslimah tidak hanya bersifat konsumtif tetapi juga bersifat produktif yaitu LKP Inun memberikan bantuan modal kepada perempuan muslimah yang sudah mengikuti pelatihan di LKP Inun misalnya modal untuk membuat bros, keset kaki, dan jilbab. Dan hasil karya perempuan di Kelurahan Sumber Karya Kecamatan Binjai Timur di serahkan kepada LKP Inun agar bisa dijual ke pasaran dan barang buatan perempuan di Kelurahan Sumber Karya Kecamatan Binjai Timur agar dapat dipamerkan di suatu pameran di Binjai. Sesudah menjual barang hasil karya perempuan di Kelurahan Sumber Karya Kecamatan Binjai Timur barulah LKP Inun dan perempuan muslimah di Kelurahan Sumber Karya Kecamatan Binjai Timur bagi hasil.

LKP Inun juga memberikan program untuk menunjang dan meningkatkan tarap hidup perempuan miskin diantaranya:

1) Memberi Pelatihan dan Keterampilan

Upaya LKP Inun dalam rangka meningkatkan keterampilan sumber daya manusia perlu diadakan keterampilan yang profesional. Pelatihan keterampilan menjahit yang bisa meningkatkan tarap hidup perempuan miskin di Kelurahan Sumber Karya Kecamatan Binjai Timur, hal tersebut diharapkan mampu menghasilkan sumber daya manusia yang tinggi dan bisa bersaing di era globalisasi sehingga dapat memenuhi kebutuhan pasar, pelatihan keterampilan merupakan kegiatan lembaga dalam bentuk intervensi pemberdayaan terhadap penerima manfaat dalam rangka meningkatkan keahlian yang berbasis bisnis.

Hal ini juga berarti melakukan perubahan prilaku, sikap, dan pengetahuan yang khusus atau spesifik, kepada penerima dan manfaat. Agar pelatihan menjadi efektif maka pelatihan harus mencakup pembelajaran atau pengalaman sebelumnya. Pelatihan harus menjadi kegiatan keorganisasian yang direncanakan dan dirancang untuk 
117 Aisyah Budi Harahap, Peranan Praktek Menjahit di Lembaga Kursus dan Pelatihan (LKP) Inun: Strategi Pemberdayaan Perempuan

Jurnal At-Taghyir : Jurnal Dakwah dan Pengembangan Masyarakat Desa

Volume 1 Nomor 2 Juni 2019, h. 102-120

menanggapi permasalahan yang ada di masyarakat. Pelatihan keterampilan akan berjalan optimal apabila didukung dengan panduan pelaksanaan yang jelas dan konkrit agar mudah dilakukan oleh pelaksanaan dan perempuan sebagai orang yang diberdayakan. Pelatihan keterampilan ini lebih difokuskan pada pelatihan menjahit yang dimana bantuan biaya belajarnya sudah ditanggung oleh pemerintah. LKP Inun akan mempasilitasi dan memberikan pelatihan menjahit ini dengan gratis tidak dipungut biaya.

2) Pemberian Sarana Usaha

Sarana usaha adalah alat penunjang dalam proses produksi pemberian sarana usaha merupakan salah satu kegiatan lembaga untuk memberikan perlengkapan guna untuk menunjang kelancaran usaha penerima manfaat. Aktivitas pemberian sarana usaha menjadi penting karena apabila sarana usaha tidak tersedia maka perputaran usaha penerima manfaat menjadi tersandat dan terhambat kemajuannya agar pengelola pemberian sarana usaha dapat terorganisasi dengan baik sesuai dengan tujuan dari kegiatan, maka perlu dibuat ketentuan prosedur pelaksanaan pemberian sarana usaha. Pemberian sarana usaha berupa alat-alat yang dibutuhkan perempuan yang akan diberikan pelatihan menjahit seperti mesin jahit, benang, jarum jahit, dll. Dan alat-alat yang dibutuhkan tersebut sudah tersedia dan diletakkan di LKP Inun, jika perempuan muslimah di Kelurahan Sumber Karya Kecamatan Binjai Timur membutuhkan alat-alat tersebut hanya bisa digunakan di lokasi LKP Inun.

3) Memberikan Pendampingan Usaha

Pendampingan usaha sangatlah diperlukan dalam memberdayakan perempuan di Kelurahan Sumber Karya Kecamatan Binjai Timur yang dimana bertujuan untuk mengatur tatacara pendampingan penerima manfaat terkait usaha yang dilakukan meliputi motivasi usaha, dan bagaimana penjualan produk yang dihasilkan, ketentuan pendamping usaha adalah sebagai berikut:

a) Syarat penerima manfaat harus terdaftar menjadi penerima manfaat sesuai dengan ketentuan dalam dalam intruksi kerja survei penerima manfaat bersedia didampingi dalam bidang pembangunan usaha perempuan di Kelurahan Sumber Karya Kecamatan Binjai Timur selama mengikuti program Lembaga Kursus dan Pelatihan Inun dengan mengisi surat pernyataan komitmen penerima manfaat. 
118 Aisyah Budi Harahap, Peranan Praktek Menjahit di Lembaga Kursus dan Pelatihan (LKP) Inun: Strategi Pemberdayaan Perempuan

Jurnal At-Taghyir : Jurnal Dakwah dan Pengembangan Masyarakat Desa

Volume 1 Nomor 2 Juni 2019, h. 102-120

b) Pelaksana pendampingan usaha terbagi menjadi 3 kegiatan yaitu:

Pemberian motivasi; Kegiatan ini memberatkan kepada pemberi materi-materi membangkitkan semangat bagi perempuan miskin agar pola pikir dan mental mereka berubah menjadi lebih baik, pendamping yang dilakukan dengan cara memberikan motivasi, masukan kreativitas kepada perempuan miskin agara lebih mampu mengembangkan usaha yang sedang dijalani. Penjualan produk; Kegiatan penjualan produk ini dengan cara mempasilitasi perempuan miskin di Kelurahan Sumber Karya Kecamatan Binjai Timur melakukan penjualan dengan metode yang tepat, sumber daya manusia sebagai pelaksana diperbolehkan ikut menjual produk perempuan di Kelurahan Sumber Karya Kecamatan Binjai Timur dalam rangka membantu membuka jaringan penjualan.

c) Kelompok usaha kecil mandiri

Kelompok usaha kecil mandiri ini merupakan program pemberdayaan dan pendampingan ekonomi berbasis mikro, memberi program dalam bentuk pengadaan modal serta sarana penunjang aktivitas yang telah dimiliki. Bantuan sarana usaha dan modal yang diberikan berdasarkan hasil kebutuhan perempuan yang ingin diberdayakan, program bantuan usaha kecil merupakan upaya yang dilakukan dalam mendorong perekonomian perempuan muslimah di Kelurahan Sumber Karya Kecamatan Binjai Timur supaya menjadi perekonomian yang lebih baik. Keahlian suatu lembaga juga dilihat dari kemampuannya melakukan berbagai usaha untuk meningkatkan kesejahteraan hidupnya, program kerja yang telah direncanakan harus diaplikasikan dalam berbagai bentuk kegiatan, kegiatan-kegiatan yang dilakukan inilah yang menunjukkan keberhasilan para mengurus menjalankan kinerja lembaga yang telah dibuat. LKP Inun selalu membina dan melihat perkembangan perempuan muslimah yang telah diberdayakan supaya mereka itu mendapatkan kehidupan yang meningkat tidak hanya kualitas SDM meningkat tetapi perekonomian perempuan muslimah di Kelurahan Sumber Karya Kecamatan Binjai Timur juga meningkat.

4. Ekonomi Perempuan Muslimah Sesudah Mendapat Bantuan dari LKP Inun

Pemberdayaan yang diberikan LKP Inun melalui program menjahit memiliki dampak yang menjanjikan dalam menuntaskan kemiskinan, dan hal inipun sudah dibuktikan oleh LKP Inun terhadap perempuan muslimah di Kelurahan Sumber Karya 
119 Aisyah Budi Harahap, Peranan Praktek Menjahit di Lembaga Kursus dan Pelatihan (LKP) Inun: Strategi Pemberdayaan Perempuan

Jurnal At-Taghyir : Jurnal Dakwah dan Pengembangan Masyarakat Desa

Volume 1 Nomor 2 Juni 2019, h. 102-120

Kecamatan Binjai Timur. Perempuan di Kelurahan Sumber Karya Kecamatan Binjai Timur perekonomiannya menengah ke bawah mendapatkan bantuan oleh LKP Inun supaya kehidupan mereka lebih baik dari segi ekonomi dan pendidikannya. Pihak LKP Inun mengatakan dampak dari pemberdayaan yang diberikan melalui program menjahit kepada perempuan muslimah di Kelurahan Sumber Karya Kecamatan Binjai Timur itu bersifat positif, karena LKP Inun sudah melihat langsung terhadap kehidupan perempuan yang telah diberdayakan.

Kehidupan perempuan di Kelurahan Sumber Karya Kecamatan Binjai Timur semakin baik dari segi ekonominya dan kualitas SDM mereka juga semakin meningkat. Perempuan yang diberyakan LKP Inun sudah dapat membuka usaha menjahit sendiri, dan mereka tidak hanya bergantung terhadap keluarga bahkan mereka dapat membantu perekonomian dikeluarga. Dampak pemberdayaan kepada perempuan muslimah itu memang tidak semuanya bersifat positif karena sebagian perempuan muslimah yang diberdayakan tidak mau berusaha setelah LKP Inun memberikan pelatihan menjahit.

\section{Penutup}

Program yang dilakukan LKP Inun dalam praktek menjahit secara gratis yaitu usaha yang dilakukan pemerintah untuk mengurangi pengangguran dan dapat memberdayakan perempuan di Kelurahan Sumber Karya Kecamatan Binjai Timur. Sesudah mempelajari semua materi menjahit diharapkan para perempuan dapat membuka usaha sendiri di rumah dengan hasil usaha ini dapat meningkatkan ekonomi keluarga. Dalam pelatihan keterampilan menjahit ini bukan hanya pengetahuan menjahit saja yang mereka dapatkan, akan tetapi juga mempererat Ukhuah Islamiyah dari segi silaturrahmi. Intruksi pelatihan keterampilan menjahit ini pun sangat berpengalaman bahkan sudah mempunyai usaha konveksi sendiri dan juga toko pakaian sendiri. Ibu Nurainun diamanahkan pemerintah untuk memberi pengetahuan menjahit kepada perempuan di Kelurahan Sumber Karya Kecamatan Binjai Timur agar perempuan mampu mencapai kehidupan yang lebih baik. 
120 Aisyah Budi Harahap, Peranan Praktek Menjahit di Lembaga Kursus dan Pelatihan (LKP) Inun: Strategi Pemberdayaan Perempuan

Jurnal At-Taghyir : Jurnal Dakwah dan Pengembangan Masyarakat Desa

Volume 1 Nomor 2 Juni 2019, h. 102-120

\section{Daftar Kepustakaan}

Alfitri, Community Development, Yogyakarta : Pustaka Pelajar, 2011.

Ali, M. Hasan, Masail Fiqhiyah Al- Haditsah pada Masalah-Masalah Kontemporer Hukum Islam, Jakarta: PT RajaGrafindo Persada, 1998.

Aprillia, et al Pembangunan Berbasis Masyarakat, Bandung: Cv. Alfabeta, 2014.

Arifin Zakaria, Zainal, Tafsir Inspirasi, Medan: Duta Azahar, 2012.

https://binjaikota.bps.go.id/frontend/LinkTabelStatis/view/id/199, diakses tanggal 31 Maret 2019, jam 19.00 WIB.

ITB, Ikatan Alumni, Pembaruan dan Pemberdayaan, Jakarta: ITB Press, 1996.

Kh, Sutrisno dan Johnston, Mary, Membina Masyarakat Pembangunan Kasus-Kasus Pengembangan Masyarakat, Surakarta : Yayasan Indonesia Sejahtera, 1992.

Mardikanto, Totok, Soebiato, Poerwoko, Perberdayaan Masyarakat Dalam Perspektif Kebijakan Publik, Bandung: ALFABETA, 2015.

Pernama Siregar, Charles, Jalan Terjang Menuju Masyarakat Indonesia Sejahtera, Padang : BBPPKS, 2009.

Pranaka, A.M.W, Gelobalisasi Pemberdayaan dan Demokratisasi, Jakarta : CIDES, 1997.

Rukminto Adi, Isbandi, Intervensi Komunitas Pengembangan Masyarakat Sebagai Upaya Pemberdayaan masyarakat, Jakarta: PT. Raja Grapindo Persada, 2008.

R. Wrihatnolo, Randhy, Manajemen Pemberdayaan, Jakarta: PT Elex Media Komputindo, 2007.

Sahrul, Sosiologi Islam, Medan: IAIN PRESS, 2011.

Winarni, Memahami Pemberdayaan Masyarakat Desa Primitif dalam Orientasi Pembangunan Masyarakat Desa Menyongsong Abad 21: Maju Pemberdayaan Pelayanan Masyarakat, Yogyakarta: Aditya Media, 1998. 